University of Nebraska - Lincoln

DigitalCommons@University of Nebraska - Lincoln

U.S. Environmental Protection Agency Papers

U.S. Environmental Protection Agency

2009

\title{
Arsenate and Dimethylarsinic Acid in Drinking Water did not Affect DNA Damage Repair in Urinary Bladder Transitional Cells or Micronuclei in Bone Marrow
}

\author{
Amy Wang \\ Virginia Polytechnic Institute and State University, amywang@vt.edu \\ Andrew D. Kligerman \\ U.S. EPA \\ Steven D. Holladay \\ Virginia Polytechnic Institute and State University \\ Douglas C. Wolf \\ U.S. EPA \\ John L. Robertson \\ Virginia Polytechnic Institute and State University
}

Follow this and additional works at: https://digitalcommons.unl.edu/usepapapers

Wang, Amy; Kligerman, Andrew D.; Holladay, Steven D.; Wolf, Douglas C.; and Robertson, John L., "Arsenate and Dimethylarsinic Acid in Drinking Water did not Affect DNA Damage Repair in Urinary Bladder Transitional Cells or Micronuclei in Bone Marrow" (2009). U.S. Environmental Protection Agency Papers. 184.

https://digitalcommons.unl.edu/usepapapers/184

This Article is brought to you for free and open access by the U.S. Environmental Protection Agency at DigitalCommons@University of Nebraska - Lincoln. It has been accepted for inclusion in U.S. Environmental Protection Agency Papers by an authorized administrator of DigitalCommons@University of Nebraska - Lincoln. 


\title{
Research Article
}

\section{Arsenate and Dimethylarsinic Acid in Drinking Water did not Affect DNA Damage Repair in Urinary Bladder Transitional Cells or Micronuclei in Bone Marrow}

\author{
Amy Wang, ${ }^{1 *}$ Andrew D. Kligerman, ${ }^{2}$ Steven D. Holladay, ${ }^{1}$ \\ Douglas C. Wolf, ${ }^{2}$ and John L. Robertson ${ }^{1}$ \\ ${ }^{1}$ Department of Biomedical Sciences and Pathobiology, Virginia Maryland \\ Regional College of Veterinary Medicine, Virginia Polytechnic Institute and \\ State University (Virginia Tech), Blacksburg, Virginia 24061 \\ ${ }^{2}$ Environmental Carcinogenesis Division, National Health and Environmental \\ Effects Research Laboratory, Office of Research and Development, \\ U.S. Environmental Protection Agency (U.S. EPA), Research Triangle Park, \\ North Carolina 27711
}

measured by the Comet assay. DMA(V) effects were not observed on either CP-induced DNA damage induction or on DNA repair. Neither DMA(V) nor As(V) increased the $\mathrm{H}_{2} \mathrm{O}_{2}$ or formaldehyde-induced DNA damage, and neither inhibited the repair of $\mathrm{H}_{2} \mathrm{O}_{2}$-induced DNA damage. Neither DMA(V) nor As(V) increased the micronucleus frequency, nor did they elevate micronucleus frequency resulting from $\mathrm{CP}$ treatment above the level observed by the treatment with $\mathrm{CP}$ alone. These results suggest that arsenic carcinogenesis/cocarcinogenesis in the urinary bladder may not be via DNA damage repair inhibition. To our knowledge this is the first report of arsenic effects on DNA damage repair in the urinary bladder. Environ. Mol. Mutagen. 50:760770, 2009. Published 2009 by Wiley-Liss, Inc. *

Key words: arsenic; DNA repair; urothelium; micronucleus; comet assay

\section{INTRODUCTION}

Arsenic, a human carcinogen, is a widely distributed natural metalloid, and is used in man-made products such as herbicides. The primary arsenic exposure to the general population is through drinking water. Arsenic, namely inorganic arsenic in the forms of arsenite [As(III)] and arsenate $[\mathrm{As}(\mathrm{V})]$, in drinking water increases the incidences of cancers in lung (squamous and small cell carcinoma) [Guo et al., 2004], skin (Bowen's disease, basal and squamous cell carcinoma) [Guo et al., 2001], and urinary bladder (transitional cell carcinoma) [Chiou et al., 2001]. In addition, arsenic may act as a cocarcinogen in the urinary bladder (with cigarette smoking) [Chiou et al., 2001] and skin (with UV light exposure) [Rossman et al., 2004].

The study of arsenic carcinogenesis is complicated. The metabolism of inorganic arsenic into various organic
Amy Wang is currently an ORISE postdoctoral fellowship via an interagency agreement between Department of Energy and U.S. EPA, Research Triangle Park, NC 27711.

Douglas C. Wolf is currently at Research Planning and Coordination Staff, National Health and Environmental Effects Research Laboratory, Office of Research and Development, U.S. EPA, Research Triangle Park, NC 27711.

Steven D. Holladay is currently at Department of Anatomy and Radiology, College of Veterinary Medicine, The University of Georgia, Athens, GA 30602-7382.

*Correspondence to: Amy Wang. E-mail: amywang@vt.edu

Received 14 February 2008; provisionally accepted 25 March 2009; and in final form 25 March 2009

DOI 10.1002/em.20496

Published online 26 May 2009 in Wiley InterScience (www.interscience. wiley.com). 
arsenicals, tissue-specific distribution of the arsenicals, and arsenical-dependent toxicities and mechanisms by which adverse effects are mediated, are just a few factors that need to be considered [Kligerman and Tennant, 2006; Wang et al., 2007b]. For example, humans and rodents metabolize $\mathrm{As}(\mathrm{V})$ into $\mathrm{As}(\mathrm{III})$, and into monomethylarsonic acid [MMA(V)], monomethylarsonous acid [MMA(III)], dimethylarsinic acid [DMA(V)], and dimethylarsinous acid [DMA(III)]. In mice gavaged with As(V), DMA(V) concentrations were highest in the urinary bladder and lung, but inorganic arsenic concentrations were highest in the kidney [Hughes et al., 2003]. Trivalent arsenicals are more toxic than their pentavalent counterparts, with MMA(III) and DMA(III) being the most toxic. In humans, increased incidences of urinary bladder cancer were seen after exposure to inorganic arsenic, but in laboratory animals, significantly increased incidences of urinary bladder cancer have only been observed in F344 rats exposed to DMA(V) [Wang et al., 2002]. Rats can tolerate much higher doses of inorganic arsenic than humans, and this is at least partially because of the binding of DMA(III) to red blood cells in rats [Lu et al., 2004; Cohen et al., 2007].

Several modes of action of arsenic carcinogenesis have been proposed. They include (1) oxidative stress induction, (2) DNA damage repair inhibition, (3) signal transduction pathway modulation, (4) cell proliferation increases (altered growth factors and regenerative proliferation), (5) induction of chromosomal abnormalities, and (6) DNA methylation alteration [Kitchin, 2001; Schoen et al., 2004]. These possible modes of action are not mutually exclusive. For example, arsenic-induced oxidative stress can lead to chromosomal abnormalities [Ho et al., 2000]. Furthermore, the mode of action of arsenic carcinogenesis is believed to be tissue-specific. For instance, arsenic may have a different mode of action in the bladder than in other organs because of the mixture of arsenic metabolites in the urine [Rossman, 2003].

Because arsenic is reported to be a strong comutagen and cocarcinogen, it has long been hypothesized that arsenic interferes with DNA damage repair and therefore enhances the mutagenicity and carcinogenicity of DNAdamaging agents [Vogt and Rossman, 2001; Rossman et al., 2004]. Arsenic-inhibited DNA damage repair has been reported in cultured skin and lung cells [Schwerdtle et al., 2003; Wu et al., 2005], but arsenic effects on DNA repair have not been studied in urinary bladder cells. Decreases in expression of DNA repair genes were observed in cultured cells exposed to noncytotoxic concentrations of arsenic [Hartwig et al., 2003; Clewell et al., 2006]. Decreased DNA repair gene expression occurred concurrently with increased expression of oxidative stress response genes [Hamadeh et al., 2002], suggesting decreased DNA repair of arsenic-induced oxidative damage. Recently, decreases in DNA damage repair and DNA repair gene expression were observed in lymphocytes col- lected from arsenic-exposed humans [Andrew et al., 2003; Andrew et al., 2006].

The view that decreased DNA damage repair may contribute to urinary bladder cancer risk is supported by decreases in DNA repair in carcinogen-treated bladder cells compared to normal cells [Yoshimi et al., 1989]. Also, decreased expression of DNA repair genes, but not necessarily activity, was associated with bladder cancer progression [Kawakami et al., 2004; Korabiowska et al., 2004]. Arsenic-decreased DNA damage repair in urinary bladder cells could explain, at least partially, the higher bladder cancer risk in smokers as compared to nonsmokers in the arsenic-exposed population [Chiou et al., 2001] because cigarettes contain mutagenic components, and the urine of smokers is more mutagenic than the urine of nonsmokers [Bowman et al., 2002].

Studies of F344 rats exposed to DMA(V) in diet or water [Cohen et al., 2001; Wei et al., 2002] provide evidence for the following mode of action of DMA(V)-induced bladder cancer [Sams et al., 2007]. First, DMA(V) is reduced to DMA(III), and DMA(III) causes cytotoxicity in the urothelium [Cohen et al., 2001, 2002; Sams et al., 2007]. Consequently, regenerative proliferation occurs and leads to hyperplasia and eventually bladder tumors. These events are plausible in humans, but do not exclude other modes of action, such as oxidative stress [Wei et al., 2005], chromosomal abnormalities [Moore et al., 2002], or DNA damage repair inhibition.

One of the purposes of the present study was to investigate if 1-week oral exposure to $\mathrm{DMA}(\mathrm{V})$ or $\mathrm{As}(\mathrm{V})$ inhibits DNA damage repair in urinary bladder transitional cells, a target cell of arsenic carcinogenesis. $\mathrm{DMA}(\mathrm{V})$ was chosen because it can induce bladder cancer in rats, and $\mathrm{As}(\mathrm{V})$ was investigated as it is one of the common forms of arsenic that humans ingest in drinking water. Three types of DNA damage repair were studied: (1) in vivo repair of cyclophosphamide (CP)-induced DNA damage, which includes DNA strand breaks and DNA-DNA crosslinks, (2) in vitro repair of hydrogen peroxide $\left(\mathrm{H}_{2} \mathrm{O}_{2}\right)$-induced DNA damage, which is mainly oxidative DNA damage, and (3) in vitro repair of formaldehyde-induced DNA-protein crosslinks.

We also investigated whether in vivo exposure of $\operatorname{DMA}(\mathrm{V})$ or $\mathrm{As}(\mathrm{V})$ increases micronucleus (MN) frequencies in the bone marrow. A MN is the result of either chromosomal breakage or chromosome malsegregation. Humans exposed to arsenic through drinking water showed increased MN frequencies in cells of various tissues, and MN have been suggested as a biomarker of arsenic exposure [Moore et al., 1997; Feng et al., 2001; Tian et al., 2001; Basu et al., 2004; Chakraborty et al., 2006].

\section{MATERIALS AND METHODS}

\section{Chemicals}

Arsenic [IARC, 2004], CP [IARC, 1987], and formaldehyde [IARC, 2006] are human carcinogens. Beuthanasia and sodium hydroxide 
$(\mathrm{NaOH})$ are also hazardous to human health and should be handled with care.

For animal treatments, DMA(V) $\left[\left(\mathrm{CH}_{3}\right)_{2} \mathrm{As}(\mathrm{O}) \mathrm{OH}\right]$ (CAS no. 75-60$5 \mathrm{O}$ ), purity $>99 \%$, was purchased from Sigma, St. Louis, MO. As(V) in the form of sodium hydrogen arsenate heptahydrate $\left[\mathrm{Na}_{2} \mathrm{HAsO}_{4} \cdot 7 \mathrm{H}_{2} \mathrm{O}\right]$ (CAS no. 10048-95-0), purity $>98.5 \%$, was also from Sigma. CP (CAS no. 6055-19-2), purity $>98 \%$, was purchased from MP Biomedicals, Aurora, OH. Isoflurane was from Abbott Animal Health, North Chicago, IL, and Beuthanasia was obtained from Schering-Plough Animal Health Corporation, Union, NJ.

For terminal surgeries to harvest cells, Isoflurane (CAS no. 26675-46-7) was purchased from Abbott Animal Health, North Chicago, IL. Beuthanasia [390 mg pentobarbital sodium (barbituric acid derivative) and $50 \mathrm{mg}$ phenytoin sodium per $\mathrm{ml}$ of Beuthanasia] (CAS no. 8024-20-2) was obtained from Schering-Plough Animal Health Corporation, Union, NJ.

For the Comet assay, Williams' medium E, trypsin, ethylenediaminetetraacetic acid disodium salt dihydrate $\left(\mathrm{Na}_{2}\right.$ EDTA), dimethyl sulfoxide (DMSO), $\mathrm{NaOH}$, and Trizma base were purchased from Sigma, as was formaldehyde (36.5-38\%). Fetal bovine serum (FBS) was from Cambrex Bio Science Walkersville, Walkersville, MD and Atlanta Biologicals, Lawrenceville, Ga. $\mathrm{H}_{2} \mathrm{O}_{2}$ was from Fisher Scientific, Suwanee, Georgia. Proteinase K (Catalog No. 25530-049), L-glutamine (Gibco), and SYBR gold (Molecular Probe) were obtained from Invitrogen, Grand Island, NY. Comet LMAgarose (low melting temperature agarose), Comet Lysis Solution, and FLARE slides (each slide has three sample loading areas precoated with agarose ) were purchased from Trevigen, Gaithersburg, MD. Ethanol (200 proof ethyl alcohol) was from AAPER, Shelbyville, KY.

For the MN assay, FBS (Catalog no. BW14-501C) and methanol were from Fisher Scientific, and $\mathrm{Na}_{2}$ EDTA was from Sigma. Acridine orange (Molecular Probe) was purchased from Invitrogen.

\section{Animals and Animal Care}

Animal use and procedures were approved by the Virginia Tech Institutional Animal Care and Use Committee for Animals Used in Research and Testing before the initiation of the study.

Female F344 rats, age 5-9 weeks old, were purchased from Harlan Teklad (Madison, WI). F344 rats are the only identified laboratory animals that develop urinary bladder transitional cell carcinoma from arsenic in drinking water [Wei et al., 2002] or diet [Arnold et al., 2006]. Females were chosen because their urinary bladders are more susceptible to arsenic toxicity than males [Arnold et al., 1999; Shen et al., 2006]. All rats were quarantined and acclimated for at least 2 weeks. Polycarbonate shoebox-style cages with Alpha Dry bedding (Shepherd Specialty Papers, Watertown, TN) were used to minimize dust, because both $\operatorname{DMA}(\mathrm{V})$ and CP metabolites were excreted in the urine [de Jonge et al., 2005; Shen et al., 2006]. The rats were housed in a temperature controlled room with a 12-hr light/dark cycle, and single-housed at least 1 week before the beginning of in vivo dosing. Teklad 2018 SC diet (Harlan Teklad, Madison, WI) and tap water in plastic water bottles with stainless steel sipper tubes with stoppers were available ad libitum.

\section{Animal Treatments and Experimental Design (See Table I)}

The experiment consisted of eight animal treatment groups, established to provide data to test the response to three types of DNA damage. With the exception of the negative control groups G, with four rats, and $\mathrm{H}$, with three rats, all other groups consisted of six rats (Table I). The number of animals per group was determined based on preliminary studies. Rats in Groups $\mathrm{G}$ and $\mathrm{H}$ (tap water and then 1 or 5 days of recovery) were expected to have the same levels of DNA damage and were designed to be pooled for the in vitro repair study to minimize the number of animals. Animals were treated via drinking water for 7 days with either 100 ppm DMA(V) [Groups A through D], or 100 ppm As(V)
TABLE I. Study Design All rats were given tap water, 100 ppm DMA(V), or $100 \mathrm{ppm} \operatorname{As}(\mathrm{V})$ in drinking water for 7 days. At the end of the 7-day treatment, certain rats received a single oral gavage of CP (Groups A, B, E, and F). Rats were given tap water during the recovery period. Urinary bladder transitional cells collected from rats in Groups A, B, $D, E$, and $F$ received no additional treatment. Portions of transitional cells collected from rats in Groups $\mathrm{C}, \mathrm{G}, \mathrm{H}$, and I were treated with $\mathrm{H}_{2} \mathrm{O}_{2}$ or formaldehyde for 10 minutes on ice, and then some cells were allowed to recover in medium without $\mathrm{H}_{2} \mathrm{O}_{2}$ or formaldehyde at $37^{\circ} \mathrm{C}$ for $4 \mathrm{~h}$. For measurements of $\mathrm{MN}$ and polychromatic erythrocytes frequencies, bone marrow were collected from negative control rats (Groups $G$ and $H$ ) and rats exposed to DMA(V) + CP (Group A), DMA(V) (Group C), CP (positive control, Group $\mathrm{E})$, or $\operatorname{As}(\mathrm{V})$ (Group I) 1 day after the last in vivo dosing. *indicates the group from which bone marrow was collected after in vivo dosing and in vivo recovery (without in vitro dosing or recovery)

\begin{tabular}{|c|c|c|c|c|}
\hline \multirow[b]{2}{*}{ Group } & \multicolumn{2}{|c|}{ For in vivo repair } & \multicolumn{2}{|c|}{ For in vitro repair } \\
\hline & $\begin{array}{c}\text { In vivo } \\
\text { dosing }\end{array}$ & $\begin{array}{l}\text { In vivo } \\
\text { Recovery } \\
\text { (days) }\end{array}$ & $\begin{array}{c}\text { In vitro } \\
\text { dosing }\end{array}$ & $\begin{array}{c}\text { In vitro } \\
\text { Recovery } \\
\text { (hrs) }\end{array}$ \\
\hline $\mathrm{A}^{*}$ & $\mathrm{DMA}(\mathrm{V})+\mathrm{CP}$ & 1 & - & - \\
\hline B & $\operatorname{DMA}(\mathrm{V})+\mathrm{CP}$ & 5 & - & - \\
\hline $\mathrm{C}^{*}$ & $\operatorname{DMA}(\mathrm{V})$ & 1 & $\mathrm{H}_{2} \mathrm{O}_{2}$, Formaldehyde & 0,4 \\
\hline $\mathrm{D}$ & $\mathrm{DMA}(\mathrm{V})$ & 5 & - & - \\
\hline $\mathrm{E}^{*}$ & Tap water $+\mathrm{CP}$ & 1 & - & - \\
\hline $\mathrm{F}$ & Tap water $+\mathrm{CP}$ & 0 & - & - \\
\hline $\mathrm{G}^{*}$ & Tap water & 1 & $\mathrm{H}_{2} \mathrm{O}_{2}$, Formaldehyde & 0,4 \\
\hline $\mathrm{H}^{*}$ & Tap water & 5 & $\mathrm{H}_{2} \mathrm{O}_{2}$, Formaldehyde & 0,4 \\
\hline$I^{*}$ & $\mathrm{As}(\mathrm{V})$ & 1 & $\mathrm{H}_{2} \mathrm{O}_{2}$, Formaldehyde & 0,4 \\
\hline
\end{tabular}

[Group I ]. The concentration of $\operatorname{DMA}(\mathrm{V})$ was chosen because of the increase in bladder transitional cell carcinoma in rats exposed to 100 ppm DMA(V) in 2 year exposure studies [Wei et al., 1999; Arnold et al., 2006], and the $\operatorname{As}(\mathrm{V})$ concentration was chosen to provide comparison to DMA(V) exposure. A single oral gavage of CP $(11.75 \mathrm{mg}$ $\mathrm{CP} / \mathrm{kg} \mathrm{BW}$, equivalent to $1 / 8 \mathrm{LD}_{50}$ ) was given at the end of 7-day exposure to $\operatorname{DMA}(\mathrm{V})$, and animals were allowed to recover for either 1 day [Group A] or 5 days [Group B] before the terminal surgery to collect urinary bladder cells and bone marrow. During the surgery, the rat was anesthetized by isoflurane inhalation, and the urinary bladder was treated and removed (see below Comet assay with transitional cells to detect DNA damage and repair and [Wang et al., 2007a]). The rat was then euthanized with an intracardiac injection of Beuthanasia, and the bone marrow was harvested. Previous studies showed that 1 week exposure to $100 \mathrm{ppm} \operatorname{DMA}(\mathrm{V})$ did not affect food consumption, water consumption, or body weight in F344 rats [Cohen et al., 2001]. The dose of CP (1/8 $\mathrm{LD}_{50}$ ) was determined by preliminary experiments to be noncytotoxic to urinary bladder transitional cells based on trypan blue exclusion assay;* furthermore, CP-induced DNA damage in transitional cells was detected $24 \mathrm{hr}$ after the gavage of $\mathrm{CP}$, and was not observed 5 days later as measured by alkaline Comet assay (unpublished data). Solutions of DMA(V) $(100 \mathrm{ppm})$ and $\mathrm{As}(\mathrm{V})(100 \mathrm{ppm})$ were made weekly with tap water to

*While trypan blue exclusion assay is widely used and often recommended for viability checks before the Comet assay, it is a less rigorous estimation of cell survival than the clonal survival assay [Komissarova et al., 2005]. Therefore it is possible that the treatment [CP, $\mathrm{H}_{2} \mathrm{O}_{2}$, formaldehyde, or $\mathrm{DMA}(\mathrm{V})]$ could have caused a lower viability when measured in more sensitive assays, such as the clonal survival assay, than in the trypan blue exclusion assay. 
mimic human water sources [Huff et al., 1998] and stored at room temperature. The $\mathrm{CP}$ solution $(23.5 \mathrm{mg} / 10 \mathrm{ml}$ deionized water) was made weekly and stored at $4{ }^{\circ} \mathrm{C}$ in the dark to minimize degradation [Beijnen et al., 1992].

The experiment was performed in six blocks, based on our capacity for surgery and the number of commensurate Comet assays that could be performed. Each block included one rat from groups A to F and I, and one rat from either Group $\mathrm{G}$ (blocks 2, 4, 6) or $\mathrm{H}$ (blocks 1, 2, 3, 5), with the exception that block 2 included rats from groups $\mathrm{G}$ and $\mathrm{H}$. After quarantine and acclimation, rats were assigned to one of the six blocks by age, so all rats in a block were the same age. Within each block, rats were randomly assigned to animal treatment groups.

To study DMA(V) effects on in vivo repair of CP-induced DNA damage, urinary bladder transitional cells were collected after animal treatments in all Groups and subjected to the alkaline Comet assay based on previously developed methods [Wang et al., 2007a]. Groups G and H (tap water) were for background DNA damage at each time point, and Groups E and F (tap water $+\mathrm{CP}, 1$ or 5 day recovery) provided DNA repair control data. Groups A and B [DMA(V) + CP, 1 or 5 day recovery] were our test groups. Groups $\mathrm{C}$ and $\mathrm{D}[\mathrm{DMA}(\mathrm{V}), 1$ or 5 day recovery] and Group I $[\mathrm{As}(\mathrm{V}), 1$ day recovery] provided information on the genotoxicity of selected arsenic treatments.

To study the effects of $\mathrm{DMA}(\mathrm{V})$ and $\mathrm{As}(\mathrm{V})$ on in vitro repair of DNA damage, transitional cells were collected from rats exposed to $\operatorname{DMA}(\mathrm{V})$ or $\mathrm{As}(\mathrm{V})$ with 1 day recovery (Groups $\mathrm{C}$ and I, test groups) and rats exposed to tap water (Groups $\mathrm{G}$ and $\mathrm{H}$, negative control). Collected transitional cells were treated with $\mathrm{H}_{2} \mathrm{O}_{2}$ or formaldehyde (in vitro dosing) to induce DNA damage, and DNA damage levels were measured immediately after in vitro dosing, or after $4 \mathrm{hr}$ of in vitro recovery. Both the $\mathrm{H}_{2} \mathrm{O}_{2}$ and formaldehyde in vitro dosings were in noncytotoxic, but genotoxic ranges. $\mathrm{H}_{2} \mathrm{O}_{2}$-induced DNA damage was measured by the standard alkaline Comet assay, and formaldehyde-induced DNA damage was measured by the alkaline Comet assay with and without Proteinase $\mathrm{K}$ for detecting DNA-protein crosslinks [Wang et al., 2007a].

To study $\operatorname{DMA}(\mathrm{V})$ and $\mathrm{As}(\mathrm{V})$ effects on $\mathrm{MN}$ frequencies, bone marrow was collected from rats exposed to $\operatorname{DMA}(\mathrm{V})$, $\mathrm{As}(\mathrm{V})$, or $\mathrm{DMA}(\mathrm{V})+\mathrm{CP}$ after a 1-day recovery period (Groups C, I and A), to tap water (Groups $\mathrm{G}$ and $\mathrm{H}$, negative control), and to tap water $+\mathrm{CP}$ with a 1-day recovery period (Group E, positive control). Comparing bone marrow from rats exposed to $\mathrm{DMA}(\mathrm{V})$ or $\mathrm{As}(\mathrm{V})$ (Groups $\mathrm{C}$ and $\mathrm{I}$ ) to bone marrow from rats exposed to tap water (Groups $\mathrm{G}$ and $\mathrm{H}$ ) provided data on whether $\mathrm{DMA}(\mathrm{V})$ or $\mathrm{As}(\mathrm{V})$ in drinking water induced $\mathrm{MN}$, while comparing bone marrow from rats exposed to $\mathrm{DMA}(\mathrm{V})$ or $\mathrm{DMA}(\mathrm{V})+\mathrm{CP}$ (Groups $\mathrm{C}$ and $\mathrm{A}$ ) provided data on whether DMA(V) increased CPinduced $\mathrm{MN}$.

\section{Comet Assay With Transitional Cells to Detect DNA Damage and Repair}

Methods for selective harvest of viable urinary bladder transitional cells and detailed protocols for the Comet assay in these cells were previously developed [Wang et al., 2007a]. To prevent UV light-induced DNA damage, all procedures (except after dehydration by ethanol and before staining by SYBR gold) were done under UV-free light sources. Briefly, the bladder was rinsed, inflated with a solution containing trypsin and $\mathrm{Na}_{2}$ EDTA while the rat was under anesthesia. The inflated bladder was then separated from the rat and incubated for $30 \mathrm{~min}$ before being gently scraped to remove transitional epithelium. The transitional cells were resuspended in Williams' E medium supplemented with $10 \%$ FBS and $2 \mathrm{mM}$ L-glutamine $(\mathrm{W}+\mathrm{S})$, centrifuged, and tested by trypan blue exclusion assay for an indicator of cell viability.

Transitional cells collected from rats in Groups C, G, H, and I were divided into three aliquots. These were treated with either PBS (negative control), $100 \mathrm{mM} \mathrm{H}_{2} \mathrm{O}_{2}$, or $5 \mathrm{mM}$ formaldehyde for $10 \mathrm{~min}$ on ice (in vitro dosing). Half the cells from each in vitro dosing were resuspended in $\mathrm{W}+\mathrm{S}$ and incubated at $37^{\circ} \mathrm{C}$ for $4 \mathrm{hr}$ to recover from the $\mathrm{H}_{2} \mathrm{O}_{2}$, formaldehyde, or PBS (negative control) treatments before being subjected to the Comet assay. Formaldehyde-treated and untreated cells were subjected to the alkaline Comet assays with and without Proteinase K. $\mathrm{H}_{2} \mathrm{O}_{2}$-treated and untreated cells were subjected to the standard alkaline Comet assay. Transitional cells collected from rats in groups A, B, D, E, and $\mathrm{F}$ were treated with PBS for $10 \mathrm{~min}$ on ice and then subjected to the standard alkaline Comet assay. All samples were tested for cell viability.

Cells were resuspended in LMAgarose at $37^{\circ} \mathrm{C}$ and were loaded onto FLARE slides. For the standard alkaline Comet assay, the cells were lysed for $1 \mathrm{hr}$, and the DNA was unwound in alkaline solution $(\mathrm{pH}>13)$ for $30 \mathrm{~min}$. Electrophoresis with alkaline solution was performed at 40 $\mathrm{V}(1 \mathrm{~V} / \mathrm{cm})$ and $300 \mathrm{~mA}$ for $30 \mathrm{~min}$. For alkaline Comet assays with and without Proteinase $\mathrm{K}$, the lysis was overnight, and slides were incubated with Proteinase $\mathrm{K}(1 \mathrm{mg} / \mathrm{ml}$ in TE buffer, $\mathrm{pH}$ 8.0) or TE buffer for $2 \mathrm{hr}$ at $37^{\circ} \mathrm{C}$. The unwinding step was $20 \mathrm{~min}$, and electrophoresis was at $32 \mathrm{~V}(0.8 \mathrm{~V} / \mathrm{cm})$ and $300 \mathrm{~mA}$ for $30 \mathrm{~min}$.

After electrophoresis, slides were neutralized and dried. Slides were randomized, stained with SYBR gold, and scored by a person without knowledge of treatments using image-analysis software Komet 5.5 (Kinetic Imaging, Liverpool, UK). For each sample, 100 Comets were scored for each Comet assay condition. The percentage of DNA in the tail was chosen as the indicator of DNA migration in Comet assays. DNA-protein crosslinks were calculated by subtracting the percentage of DNA in the tail without Proteinase $\mathrm{K}$ from the percentage of DNA in the tail with Proteinase $\mathrm{K}$.

\section{Bone Marrow MN}

MN frequencies were measured in the bone marrow of rats exposed to water (Groups $\mathrm{G}$ and $\mathrm{H}$ ), and all rats that had 1 day recovery time after chemical exposure (groups A, C, E, and I). The left femur was removed from the euthanized rat, and both ends (epiphyses) of the femur were removed. The bone marrow was flushed with FBS containing $25 \mathrm{mM}$ EDTA, which was added to prevent cell clumping. Cells were pelleted by centrifugation at $220 \mathrm{~g}$ for $5 \mathrm{~min}$ at room temperature and resuspended with $\sim 1 \mathrm{ml}$ FBS containing $25 \mathrm{mM}$ EDTA. A bone marrow smear was prepared on a glass slide by spreading a $5 \mu$ cell suspension behind a second slide. Three smears were made from each rat. The smears were air dried, fixed with $100 \%$ methanol for $10 \mathrm{~min}$, and air dried again. Slides were coded, stained with acridine orange, and scored using a fluorescent microscope. Two slides from the same rat were examined by two people independently without knowledge of treatments. Each person scored 1,000 polychromatic erythrocytes (reticulocytes; immature erythrocytes) per slide for MN frequencies, and 2,000 erythrocytes per slide for the percentage of polychromatic erythrocytes (polychromatic erythrocytes among the total erythrocyte population).

\section{Statistical Analysis}

Results are expressed as the mean \pm standard deviations, and $P<$ 0.05 was considered significant. All data were tested using SAS 9.1.3 from SAS Institute, Cary, NC, except the percentages of polychromatic erythrocytes, which were tested using Statgraphics ${ }^{\circledR}$ Plus 5.1 statistical package from Manugistics, Rockville, MD.

For testing in vivo repair of CP-induced DNA damage, analysis of variance (ANOVA) and the Tukey posthoc test were used on arcsine transformed percentages of DNA in the tail in Comet assays. For testing in vitro repair of $\mathrm{H}_{2} \mathrm{O}_{2}$-induced DNA damage ANOVA was used on untransformed percentages of DNA in the tail in Comet assays. For testing in vitro repair of formaldehyde-induced DNA damage, the arcsine transformed percentages of DNA in the tail in Comet assays were tested by ANOVA and contrast test.

For MN frequencies, ANOVA and the Tukey posthoc test were used on arcsine transformed data. Percentages of polychromatic erythrocytes 


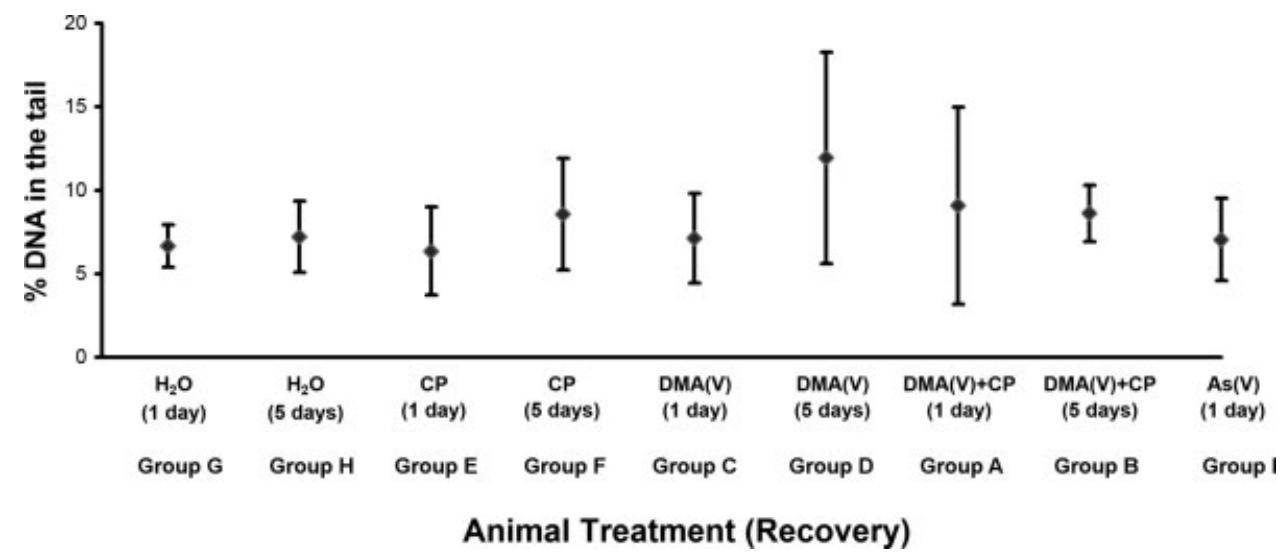

Fig. 1. DNA migration in the alkaline Comet assay without Proteinase $\mathrm{K}$ in the urinary bladder transitional cells was the same among rats exposed to in vivo dosings of water (negative control), CP, DMA(V), $\mathrm{DMA}(\mathrm{V})+\mathrm{CP}$, or As(V). DNA migration level after 5-day recovery following the in vivo dosing was not different from the DNA migration

in bone marrow were subjected to ANOVA and Duncan's multiple comparison post test.

\section{RESULTS}

\section{Cell Viability of Urinary Bladder Transitional Cells}

After the designated animal treatments (Table I), transitional cells collected from all rats had higher than $60 \%$ viabilities as measured by the trypan blue exclusion assay*, with the exception of cells from one rat each in Groups A (26\% viability) and I (55\% viability). The low viability (26\%) may have been because of insufficient trypsin and EDTA treatment during the cell collection process, and samples with less than $60 \%$ viability were excluded. Overall, the viability results suggested that the animal treatments were at worst only mildly cytotoxic to the bladder.

While transitional cells collected from rats in Groups $\mathrm{A}, \mathrm{B}, \mathrm{D}, \mathrm{E}$, and $\mathrm{F}$ were not further treated in vitro, cells collected from rats in Groups $\mathrm{C}, \mathrm{G}, \mathrm{H}$, and I were treated with $\mathrm{H}_{2} \mathrm{O}_{2}$ or formaldehyde and then underwent 0 or $4 \mathrm{hr}$ of $37^{\circ} \mathrm{C}$ incubation for recovery. Cells collected from Groups C, G, H or I showed higher than $70 \%$ viability after the $\mathrm{H}_{2} \mathrm{O}_{2}$ or formaldehyde treatments, indicating that these in vitro dosings were essentially noncytotoxic. Furthermore, most cells had greater than $70 \%$ viability after a 4-hr recovery, with only a few samples with 53 to $67 \%$ viability.

\section{DNA Damage Repair in Urinary Bladder Transitional Cells}

\section{In Vivo CP-Induced Damage}

None of the in vivo dosing regimens significantly increased DNA migration in the alkaline Comet assay af- level after 1-day recovery of the same in vivo dosing. The results showed that neither DMA(V) nor As(V) increased DNA damage in transitional cells, or that the damage was repaired within 1 day. Each diamond indicates the average percentage of DNA in the "Comet tail" for each group, and the error bar indicates standard deviation.

ter a 1-day in vivo recovery (Groups A, C, E, G, and I) (Fig. 1), indicating either that none of the in vivo exposures to DMA(V), DMA(V)+CP, $\mathrm{H}_{2} \mathrm{O}+\mathrm{CP}$, or $\mathrm{As}(\mathrm{V})$ increased DNA damage or that the damage was repaired within $24 \mathrm{hr}$. There was also no difference in DNA migration in the Comet assay between 1 and 5-day recoveries within each in vivo dosing, indicating either no delayed presence of DNA damage or a complete repair of DNA damage within $24 \mathrm{hr}$.

\section{In Vitro $\mathrm{H}_{2} \mathrm{O}_{2}$-Induced Damage}

In the test of whether DMA(V) or As(V) affects oxidative DNA damage repair, cells collected from rats in Groups C, G, H, and I [in vivo dosing of DMA(V), $\mathrm{As}(\mathrm{V})$, or tap water] were tested for the repair of in vitro $\mathrm{H}_{2} \mathrm{O}_{2}$-induced DNA damage. Cells were treated with or without $\mathrm{H}_{2} \mathrm{O}_{2}$, after which half the cells were allowed to recover in $\mathrm{H}_{2} \mathrm{O}_{2}$-free medium for $4 \mathrm{hr}$ before being subjected to the standard alkaline Comet assay (Fig. 2).

In the test of whether $\mathrm{H}_{2} \mathrm{O}_{2}$ increased DNA damage and whether any in vivo dosing increased cellular sensitivity to $\mathrm{H}_{2} \mathrm{O}_{2}$ genotoxicity, DNA migrations in the Comet assay from all samples with $0 \mathrm{hr}$ in vitro recovery (with or without $\mathrm{H}_{2} \mathrm{O}_{2}$ treatment) were tested by an ANOVA. As expected, $\mathrm{H}_{2} \mathrm{O}_{2}$ significantly increased DNA damage. None of the 7-day in vivo exposures to DMA(V) or $\mathrm{As}(\mathrm{V})$ significantly affected the cellular sensitivity to $\mathrm{H}_{2} \mathrm{O}_{2}$ genotoxicity.

In the test of whether repair of $\mathrm{H}_{2} \mathrm{O}_{2}$-induced DNA damage was affected by in vivo exposure to $\mathrm{As}(\mathrm{V})$ or DMA(V), DNA migrations in the Comet assay from samples treated with $\mathrm{H}_{2} \mathrm{O}_{2}$ after $4 \mathrm{hr}$ in vitro recovery were subjected to an ANOVA. There were no significant in vivo dosing effects, indicating DNA damage levels after 4 hr of recovery were the same among $\mathrm{H}_{2} \mathrm{O}_{2}$-treated cells 


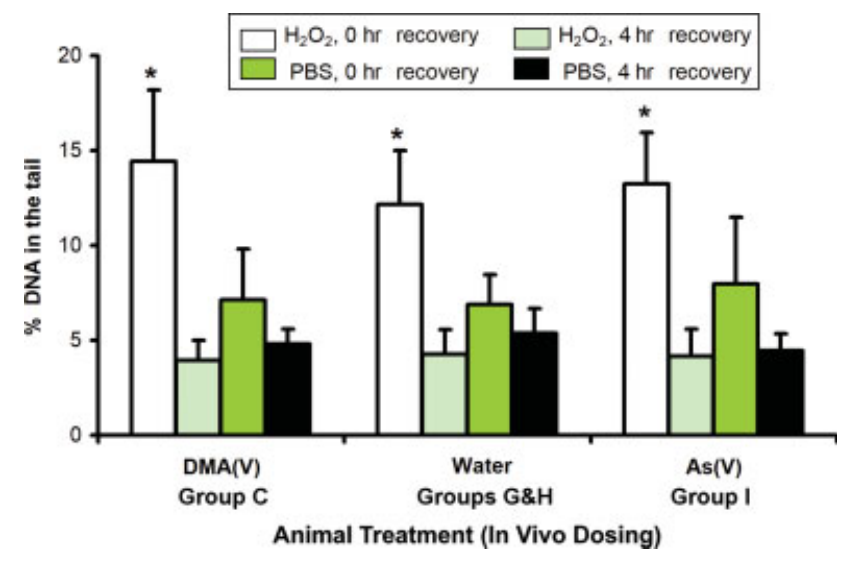

Fig. 2. The repair of in vitro $\mathrm{H}_{2} \mathrm{O}_{2}$-induced DNA damage in urinary bladder transitional cells was not affected by $\operatorname{DMA}(\mathrm{V})$ or $\mathrm{As}(\mathrm{V})$ exposures through drinking water. Transitional cells from rats exposed to 100 ppm DMA(V) (Group C), 100 ppm As(V) (Group I) in drinking water for 7 days had the same levels of DNA damage as cells from rats exposed to tap water (Groups $\mathrm{G}$ and $\mathrm{H}$ ). After in vitro exposure to $\mathrm{H}_{2} \mathrm{O}_{2}$, DNA damage levels in all four groups were the same. * indicates significant difference from PBS-treated cells at the same recovery time. [Color figure can be viewed in the online issue, which is available at www.interscience.wiley.com.]

collected from rats exposed in vivo to $\mathrm{DMA}(\mathrm{V}), \mathrm{As}(\mathrm{V})$, or tap water. These data showed that no effects from 7day in vivo exposures to $\mathrm{DMA}(\mathrm{V})$ or $\mathrm{As}(\mathrm{V})$ on the repair of in vitro $\mathrm{H}_{2} \mathrm{O}_{2}$-induced DNA damage were observed.

\section{In Vitro Formaldehyde-Induced Damage}

Cells collected from rats in Groups C, G, H, and I were also tested for repair of in vitro formaldehydeinduced DNA-protein crosslinks. Cells were treated with or without formaldehyde, after which half the cells were allowed to recover in formaldehyde-free medium for $4 \mathrm{hr}$. Comet assays with and without Proteinase $\mathrm{K}$ were performed, and the results are shown in Figure 3. The bulky protein in DNA-protein crosslinks decreases DNA migration rate in Comet assay, so cells with DNA-protein crosslinks show decreased DNA migration in Comet assay. Proteinase $\mathrm{K}$ removes protein and frees the previously protein-crosslinked DNA to migrate at a regular rate, but Proteinase K does not affect DNA or DNA-DNA crosslinks. Therefore, the differences in DNA migration in Comet assays with and without Proteinase $\mathrm{K}$ provide an indication of DNA-protein crosslink levels. In our study, the effects of formaldehyde treatment (in vitro dosing), in vitro recovery, and Proteinase $\mathrm{K}$ treatment were significant, indicating that these treatments affected DNA migration in Comet assays through the induction of DNAprotein crosslinks, and their subsequent removal by Proteinase K. However, the effects of in vivo dosing with the arsenicals were not statistically significant, indicating that neither $\mathrm{As}(\mathrm{V})$ nor $\mathrm{DMA}(\mathrm{V})$ affected the DNA migration in Comet assays.
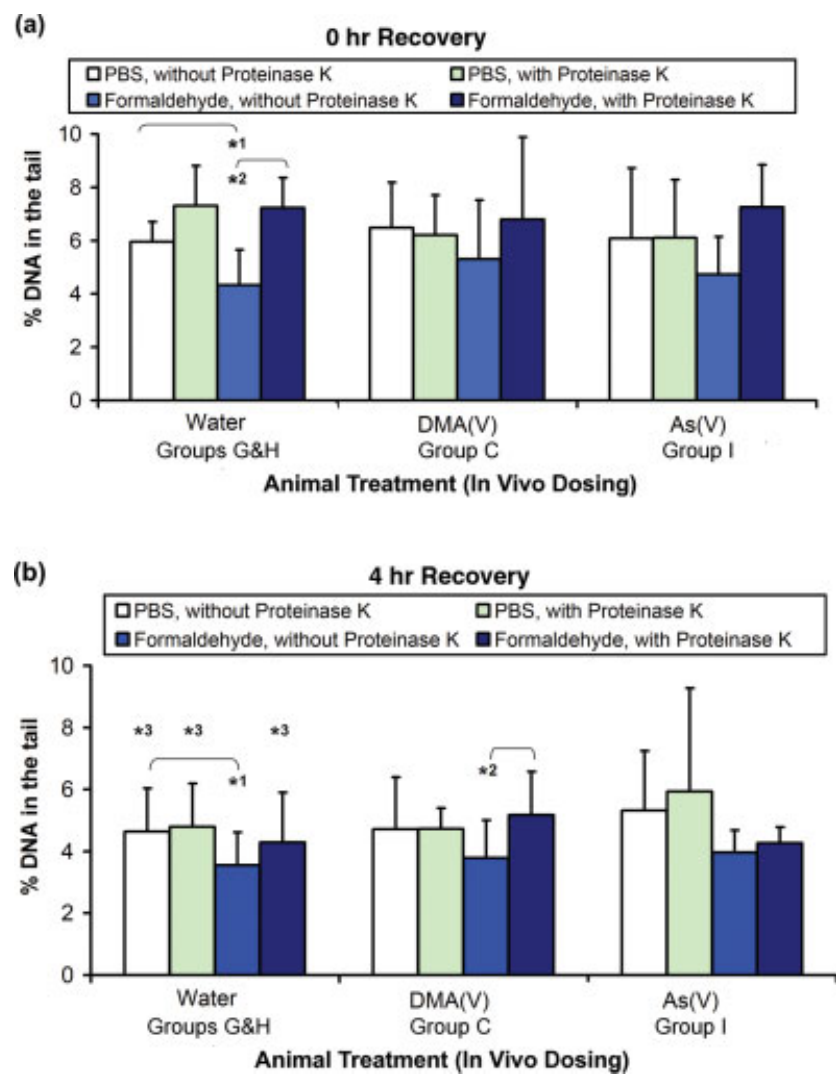

Fig. 3. DNA migration in formaldehyde-treated and control urinary bladder transitional cells after $0 \mathrm{hr}$ (a) or $4 \mathrm{hr}$ (b) of recovery. The animal treatments were the same as in Figure 2. In negative controls (Groups $\mathrm{G}$ and $\mathrm{H}$ ), formaldehyde decreased DNA migration in the Comet assay without Proteinase K at both 0 - and 4-hr recoveries. When Proteinase $\mathrm{K}$ was used there were significant increases in DNA migration in the Comet assay at 0 -hr recovery. This suggested the presence of DNA-protein crosslinks after formaldehyde treatment. In DMA(V)- and As(V)-treated rats (Groups C and I), in vitro formaldehyde caused decreases in DNA migration in the Comet assay without Proteinase K, but these did not reach statistical significance. $* 1$ indicates a significant difference from PBS-treated cells (same Comet assay, at the same recovery time), $* 2$ indicates a significant difference from Comet assays with Proteinase $\mathrm{K}$ (same sample, at the same recovery time), *3 indicates a significant difference from the same sample in the same Comet assay test at 0 -hr recovery. [Color figure can be viewed in the online issue, which is available at www.interscience.wiley.com.]

In cells collected from rats exposed to tap water (Groups $\mathrm{G}$ and $\mathrm{H}$ ), formaldehyde significantly decreased DNA migration when no Proteinase $\mathrm{K}$ was used, but not when Proteinase $\mathrm{K}$ was used at $0 \mathrm{hr}$. This indicated that DNA-protein crosslinks were induced by formaldehyde. After $4 \mathrm{hr}$ of recovery, formaldehyde-treated cells from rats exposed to tap water did not exhibit significant differences in DNA migrations in Comet assays with and without Proteinase $\mathrm{K}$, indicating the lack of DNA-protein crosslinks. Because DNA migration in the Comet assays was also significantly decreased within $4 \mathrm{hr}$ when no Proteinase $\mathrm{K}$ was used, it can be inferred that the observed 
decrease in DNA-protein crosslinks was due at least partially to the repair of strand breaks, alkaline labile sites, or incomplete excision repair sites.

In the cells collected from rats exposed to $\mathrm{As}(\mathrm{V})$ or DMA(V), formaldehyde-induced decreases in DNA migration in Comet assays without Proteinase $\mathrm{K}$, and increases after Proteinase $\mathrm{K}$ treatment did not reach the 0.05 level of significance. However, the same trends (slight decreases in DNA migration in formaldehydetreated cells as compared to PBS-treated cells, and slight increases in DNA migration by Proteinase $\mathrm{K}$ treatment in formaldehyde-treated cells as compared to no Proteinase $\mathrm{K}$ treatment) were seen in those animals drinking tap water. The exact reasons are unknown but may be because of the slightly higher variances seen in the animals on $\operatorname{DMA}(\mathrm{V})$ and $\mathrm{As}(\mathrm{V})$.

\section{MN and Polychromatic Erythrocytes in Bone Marrow}

The $\mathrm{MN}$ frequencies were increased in bone marrow collected from rats exposed to $\mathrm{CP}$ (Group E; positive control) or DMA(V)+CP (Group A) as compared to the MN frequencies in those rats exposed to tap water (Groups $G$ and $\mathrm{H}$; negative control) (Fig. 4). The $\mathrm{MN}$ frequencies were not significantly different between samples from rats exposed to DMA(V)+ CP vs. CP alone (Groups A and $\mathrm{E})$, indicating an absence of additive or synergetic effects between $\mathrm{DMA}(\mathrm{V})$ and $\mathrm{CP}$ on $\mathrm{MN}$ formation. $\mathrm{MN}$ frequencies in the bone marrow from rats exposed to DMA(V) or As(V) (Groups C and I) were not significantly different from those of rats exposed to tap water (Groups $\mathrm{G}$ and $\mathrm{H}$ ). Both the exposures to $\mathrm{CP}$ (positive control) and DMA(V)+CP decreased erythrocyte production, based on the significantly lower percentages of polychromatic erythrocytes in bone marrow collected from rats exposed to $\mathrm{CP}$ or $\mathrm{DMA}(\mathrm{V})+\mathrm{CP}$ (Groups $\mathrm{E}$ or $\mathrm{A}$, respectively) as compared to the negative control (Groups $\mathrm{G}$ and $\mathrm{H}$ ) (Fig. 5). Neither DMA(V) nor As(V) affected erythrocyte production in rats.

\section{DISCUSSION}

Arsenic inhibition of DNA damage repair has been reported in various cell types, but it has not been previously studied in urinary bladder transitional cells, a major target of arsenic carcinogenesis/cocarcinogenesis. In the present study, we measured arsenic effects on in vivo and in vitro exposures to DNA damaging agents in transitional cells freshly collected from rats. The use of newly harvested transitional cells provided several benefits in accurately assessing arsenic effects compared to studies using whole bladders or bladder cell lines. First, arsenic carcinogenesis is cell-type specific, so the use of only transitional cells avoids potentially misleading information from other types of cells in the bladder. Secondly, urothe- lial cell lines, such as HUC-1 and UROtsa, may have inactivated p53 protein because of transformation with SV40 large T antigen [Rossi et al., 2001; Su et al., 2006]. Studies showed that cells without functional p53 proteins were more sensitive to arsenic and have different cellular responses than cells with functional p53 [Kircelli et al., 2007]. Rats used in our study have normal expression of wild-type p53, and the status of p53 was not tested in the primary cell cultures of urinary bladder transitional cells. The present study showed that urinary bladder transitional cells from rats exposed to $\mathrm{DMA}(\mathrm{V})$ through drinking water did not show altered cellular sensitivity to in vivo $\mathrm{CP}$ - or in vitro formaldehyde-induced DNA damage, or reduced repair of in vitro $\mathrm{H}_{2} \mathrm{O}_{2}$-induced DNA damage. Similarly, transitional cells from rats exposed to $\mathrm{As}(\mathrm{V})$ through drinking water did not show altered sensitivity to in vitro formaldehyde-induced DNA damage or reduced repair of in vitro $\mathrm{H}_{2} \mathrm{O}_{2}$-induced DNA damage. Furthermore, neither DMA(V) nor $\mathrm{As}(\mathrm{V})$ exposure induced $\mathrm{MN}$ in the bone marrow, and $\mathrm{DMA}(\mathrm{V})$ did not increase $\mathrm{CP}$ induced MN.

Various DNA damage repair pathways are responsible for the repair of specific types of DNA damage. Previously reported arsenic-inhibited DNA damage repair pathways include (1) base excision repair (BER) [Le and Weinfeld, 2004], (2) nucleotide excision repair (NER) [Wu et al., 2005; Andrew et al., 2006], and (3) nonhomologous end joining or homologous recombination. The mismatch repair pathway was probably not affected by arsenic because microsatellite instability was not altered in DMA(V)-induced rat bladder transitional cell carcinoma [Wei et al., 2002]. Our observation that neither DMA(V) nor $\mathrm{As}(\mathrm{V})$ affected the repair of $\mathrm{H}_{2} \mathrm{O}_{2}$-induced DNA damage suggests that BER in the urinary bladder transitional cells was not significantly affected by $100 \mathrm{ppm}$ of these arsenicals. Alternatively, effects on the BER pathway could be transitory and thus not seen in cells removed and treated in vitro with DNA damaging agents in our study. It is also possible that DNA repair in urinary bladder transitional cells is only affected by a longer-term exposure to arsenic than the 1-week exposure in this study. Similarly, formaldehyde-induced DNA-protein crosslinks are believed to be removed partially by spontaneous hydrolysis [Quievryn and Zhitkovich, 2000] and by NER, proteasome-assisted proteolysis followed by NER, or homologous recombination repair with NER components [Barker et al., 2005]. Although both $\operatorname{DMA}(\mathrm{V})$ and its metabolite, DMA(III), decreased NER in a cultured human lung carcinoma cell line, A549 cells [Schwerdtle et al., 2003], in our study DMA(V) exposure through drinking water did not affect the in vitro repair or formation of formaldehyde-induced DNA-protein crosslinks in urinary bladder transitional cells.

In Schwerdtle's study [Schwerdtle et al., 2003], A549 cells were exposed to $\mathrm{DMA}(\mathrm{V})$ for $16 \mathrm{hr}$, and then to 


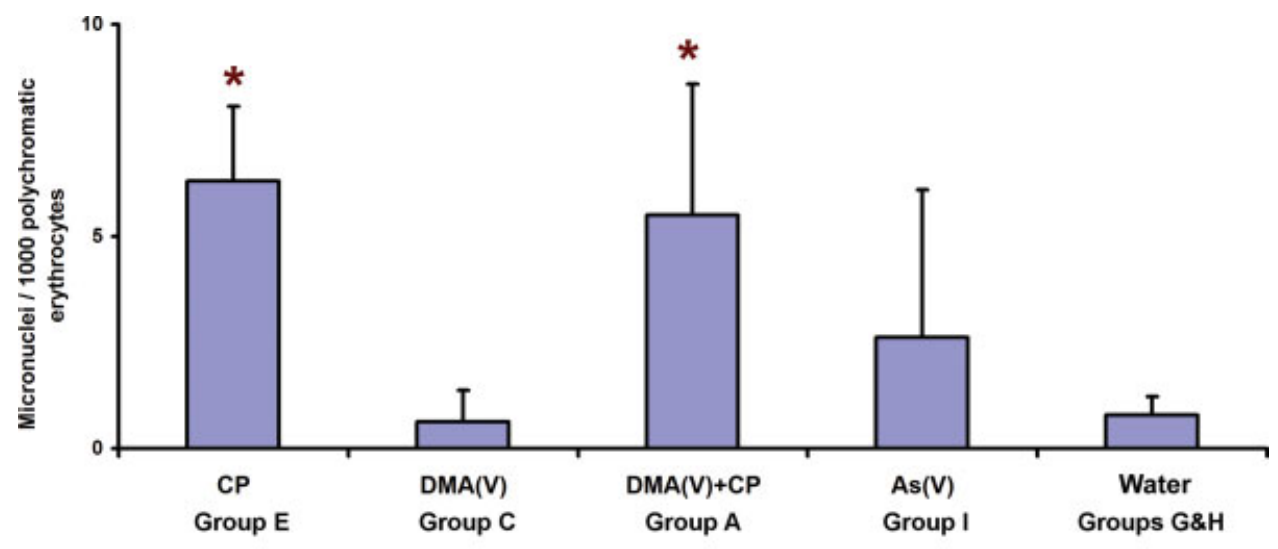

Animal Treatment (In Vivo Dosing)

Fig. 4. The frequencies of $\mathrm{MN}$ in bone marrow were not affected by 7day exposures to DMA(V) or As(V) through drinking water. CP (positive control, Group E) and DMA(V)+CP exposures (Group A) significantly increased $\mathrm{MN}$ frequencies as compared to tap water exposure (negative control, Groups $\mathrm{G}$ and $\mathrm{H}$ ). The $\mathrm{MN}$ frequencies were not significantly different among rats exposed to $\mathrm{CP}$ and $\mathrm{DMA}(\mathrm{V})+\mathrm{CP}$, indicating that $\mathrm{DMA}(\mathrm{V})$ did not enhance $\mathrm{CP}$ effects in inducing $\mathrm{MN}$. The $\mathrm{MN}$ frequencies were also not significantly different among rats exposed to DMA(V) (Group C), As(V) (Group I) and tap water, demonstrating that neither DMA(V) nor As(V) increased MN. * indicates a significant difference from negative controls [rats exposed to tap water (Groups G and $\mathrm{H})$ ]. [Color figure can be viewed in the online issue, which is available at www.interscience.wiley.com.]

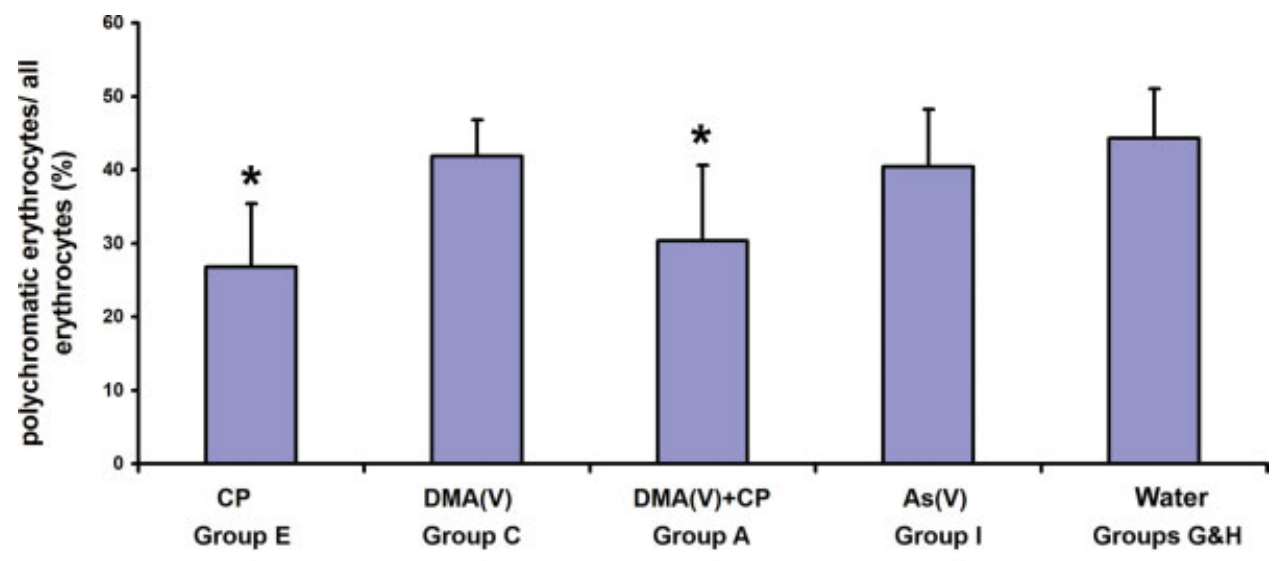

Animal Treatment (In Vivo Dosing)

Fig. 5. Erythrocyte production was not affected by 7-day exposure to $\mathrm{DMA}(\mathrm{V})$ or $\mathrm{As}(\mathrm{V})$ in drinking water. Exposures to $\mathrm{CP}$ (positive control, Group E) and DMA(V)+CP (Group A) significantly decreased polychromatic erythrocyte percentages as compared to tap water exposure (negative control, Groups $\mathrm{G}$ and $\mathrm{H}$ ), and the polychromatic erythrocyte percentages were not significantly different between CP and DMA(V) $+\mathrm{CP}$ exposures, suggesting that $\mathrm{DMA}(\mathrm{V})$ did not augment $\mathrm{CP}$-induced decreases in erythrocyte production. The polychromatic erythrocyte percentages were not significantly different among rats exposed to DMA(V) (group C), As(V) (Group I) and tap water(Groups $\mathrm{G}$ and $\mathrm{H}$ ), showing that neither $\mathrm{DMA}(\mathrm{V})$ nor $\mathrm{As}(\mathrm{V})$ decreased erythrocyte production. * indicates a significant difference from negative controls [rats exposed to tap water (Groups $\mathrm{G}$ and $\mathrm{H}$ )]. [Color figure can be viewed in the online issue, which is available at www.interscience.wiley.com.] (+)-antibenzo[a]pyrene-7,8-diol 9,10-epoxide (BPDE) for $2 \mathrm{hr}$, followed by $8 \mathrm{hr}$ of recovery in the presence of DMA(V). The repair of BPDE-DNA adducts was decreased at $250 \mu \mathrm{M} \operatorname{DMA}(\mathrm{V})$. Meanwhile, $30 \mathrm{~min}$ exposure to $10 \mathrm{mM} \mathrm{DMA}(\mathrm{V})$ caused only a slight increase in zinc release from synthesized XPA peptide (XPAzf) representing the zinc finger domain from xeroderma pigmentosum group A protein (XPA, a human zinc finger protein, involved in the recognition/incision step of NER), and no effect on the repair activity of isolated Fpg protein (an Escherichia coli zinc finger protein, involved in initiating BER). It cannot be ruled out that NER component(s) responsible for observed decreased NER in A459 cells were not involved in the removal of DNA-protein crosslinks, which could contribute to the lack of inhibition of DNA-protein crosslinks seen in our study. Compared to our study [100 ppm $(0.72 \mu \mathrm{M}) \operatorname{DMA}(\mathrm{V})$ in water for 1 week and recovery for $24 \mathrm{hr}$ in the absence of DMA(V)], 
Schwerdtle's study used a much shorter exposure of a higher concentration of DMA(V) [16 hr of exposure to $250 \mu \mathrm{M}$ DMA $(\mathrm{V})$, and then $8 \mathrm{hr}$ recovery in the presence of $\mathrm{DMA}(\mathrm{V})]$. When female F344 rats were given 100 ppm $\operatorname{DMA}(\mathrm{V})$ in water for 14 days, dimethylated arsenicals were $\sim 10 \mathrm{ppm}$ in urine and less than $1 \mathrm{ppm}$ in urinary bladder, while trimethylated arsenicals were higher than $90 \mathrm{ppm}$ in urine and approximate $3 \mathrm{ppm}$ in urinary bladder [Adair et al., 2007]. This suggested that urinary bladder cells were exposed to significantly less than 100 ppm DMA(V) in our study. While out study did not show inhibition of DNA repair, it does not necessarily contradict Schwerdtle's study (2003).

In rats and mice, DNA single strand breaks were increased in the lung after an oral gavage of $\mathrm{DMA}(\mathrm{V})$ at a higher than $\mathrm{LD}_{50}$ dose, and the DNA damage was repaired within $24 \mathrm{hr}$ after the gavage [Yamanaka et al., 1989]. In cultured bladder cells, As(V) and DMA(V) were the least potent in inducing DNA damage among six trivalent and pentavalent arsenicals [Wang et al., 2007b]. In the present study, urinary bladder transitional cells collected from rats 1 day after 1-week exposure to DMA(V) or As(V) did not show increases in DNA damage. In studies by Cohen et al. [2001], increased necrosis and exfoliation in the urothelium were observed under scanning electron microscope after 1-week exposure to $100 \mathrm{ppm} \operatorname{DMA}(\mathrm{V})$, and necrotic and exfoliated (severely damaged or dead) cells may have more DNA damage than healthy cells. It is plausible that our data reflected either a recovery from DMA(V)-induced DNA damage within $24 \mathrm{hr}$ through DNA repair or loss of heavily damaged cells via exfoliation.

The effects of arsenic on the MN frequency depend on the arsenic species and exposure doses. Inorganic arsenic in drinking water [a mixture of $\mathrm{As}(\mathrm{III})$ and $\mathrm{As}(\mathrm{V})$ ] increased MN frequencies in various tissues/cells of humans (exfoliated bladder cells in China [Tian et al., 2001], Chile [Moore et al., 1997], India [Basu et al., 2004], and USA [Warner et al., 1994]; buccal mucosal cells in China [Feng et al., 2001; Tian et al., 2001] and India [Chakraborty et al., 2006]; airway epithelial cells in sputum in China [Tian et al., 2001]). In these studies, the concentrations of arsenic in water in exposed or high exposure groups ranged from $66.75 \mu \mathrm{g} / \mathrm{l}$ [Chakraborty et al., 2006], $215 \mu \mathrm{g} / \mathrm{l}$ [Basu et al., 2004] to 500-1000 $\mu \mathrm{g} / \mathrm{l}$ [Feng et al., 2001; Moore et al., 1997; Tian et al., 2001] or even above $1.3 \mathrm{mg} / \mathrm{l}$ [Warner et al., 1994], and the arsenic concentrations in low exposure or control ranged from $15 \mu \mathrm{g} / \mathrm{l}$ to no exposure. As(III) increased bone marrow $\mathrm{MN}$ frequencies in mice that received $\mathrm{As}$ (III) at 50 $\mathrm{mg} / \mathrm{l}$ in drinking water for 7 days [Lewinska et al., 2007] and rats that were intraperitoneally injected with As(III) at 5-20 mg $/ \mathrm{kg}$ body weight /day for 5 days [Patlolla and Tchounwou, 2005; Lewinska et al., 2007], but the frequency of $\mathrm{MN}$ was not increased by $\mathrm{As}(\mathrm{V})$ in mice exposed to 50,200 or $500 \mu \mathrm{g} A s(\mathrm{~V}) / 1$ in water for 12 months [Palus et al., 2006]. The effects of DMA(V) on MN were only previously studied in vitro, and DMA(V) did not increase $\mathrm{MN}$ frequency after exposure at $5 \mathrm{mM}$ for $1 \mathrm{hr}, 10$ times the cytotoxic concentration $(500 \mu \mathrm{M}$ for $1 \mathrm{hr}$ ), in Chinese hamster ovary (CHO-9) cells [Dopp et al., 2004]. Although rats show a higher tolerance to arsenic toxicity and higher arsenic (namely DMA(III)) binding to red blood cells than humans, rats are still considered a good animal model for arsenic toxicity/carcinogenicity studies [Sams et al., 2007]. Furthermore, F344 rats are the only laboratory animals which have shown arsenic-induced urinary bladder cancer. Our finding, in which neither $\mathrm{As}(\mathrm{V})$ nor $\mathrm{DMA}(\mathrm{V})$ exposure through drinking water increased $\mathrm{MN}$ frequency in rat bone marrow, is consistent with previous reports.

The arsenic species that directly induce $\mathrm{MN}$ are not clear. Dopp et al. [2004] showed that MN were induced in Chinese hamster ovary ( $\mathrm{CHO})$ cells in vitro by DMA(III) and MMA(III), but not by inorganic arsenic, MMA(V), or DMA(V). However, injections of dimethylarsinous iodide, which is presumed to form DMA(III) by hydrolysis in aqueous solution, did not increase $\mathrm{MN}$ in mouse peripheral blood [Kato et al., 2003]. Additionally, while neither DMA(V) nor dimethylarsinous iodide injections increased $\mathrm{MN}$ frequencies, $\mathrm{MN}$ frequencies were increased by coinjections of either (1) DMA(V) and reduced glutathione (GSH) or (2) dimethylarsinous iodide and GSH [Kato et al., 2003]. Because dimethylarsine was observed when DMA(V) and GSH were present, the authors suggested free radicals generated from the reaction of dimethylarsine with molecular oxygen, and not DMA(III) itself, may be the direct cause of MN.

In summary, F344 rats exposed to $100 \mathrm{ppm}$ DMA(V) or $\mathrm{As}(\mathrm{V})$ in the drinking water for 1 week did not show alterations in the sensitivity to $\mathrm{CP}$ - or formaldehydeinduced DNA damage, or in the repair of $\mathrm{H}_{2} \mathrm{O}_{2}$-induced DNA damage in urinary bladder transitional cells. Neither DMA(V) nor As(V) exposure increased $\mathrm{MN}$ frequencies in the bone marrow, and $\mathrm{DMA}(\mathrm{V})$ did not increase $\mathrm{CP}$ induced MN. Other mechanisms, such as oxidative stress, increases in cell proliferation, and alteration in metabolism of other chemicals, may contribute to arsenic carcinogenesis/cocarcinogenesis in the urinary bladder. It also cannot be ruled out that longer exposures to lower concentrations of arsenic, closer to human exposure conditions than our 1 week exposure study, may cause DNA repair inhibition in urinary bladder transitional cells.

\section{ACKNOWLEDGMENTS}

The authors thank the Clinical Research Laboratory, Delbert Jones, and Kristel Fuhrman (Virginia Tech) for their assistance in sample collection, and Alan Tennant and Jim Campbell (EPA, Research Triangle Park, NC) for their assistance in sample scoring. The authors also thank Kathy Lowes 
and Dr. Thomas Caceci (Virginia Tech) for the their assistance in electron microscopy study, and Drs. Julian Preston, Stephen Edwards, and Don Delker (EPA, Research Triangle Park, NC) for their reviews and suggestions on this manuscript. This article was reviewed by the National Health and Environmental Effects Research Laboratory, U.S. Environmental Protection Agency and approved for publication. Approval does not signify that the contents necessarily reflect the views and policies of the Agency nor does mention of trade names or commercial products constitute endorsement or recommendation for use.

\section{REFERENCES}

Adair BM, Moore T, Conklin SD, Creed JT, Wolf DC, Thomas DJ. 2007. Tissue distribution of dimethylated arsenic and its metabolites in dimethylarsinic acid- or arsenate-treated rats. Toxicol Appl Pharmacol 222:235-242.

Andrew AS, Burgess JL, Meza MM, Demidenko E, Waugh MG, Hamilton JW, Karagas MR. 2006. Arsenic exposure is associated with decreased DNA repair in vitro and in individuals exposed to drinking water arsenic. Environ Health Perspect 114:1193-1198.

Andrew AS, Karagas MR, Hamilton JW. 2003. Decreased DNA repair gene expression among individuals exposed to arsenic in United States drinking water. Int J Cancer 104:263-268.

Arnold LL, Cano M, St John M, Eldan M, van Gemert M, Cohen SM. 1999. Effects of dietary dimethylarsinic acid on the urine and urothelium of rats. Carcinogenesis 20:2171-2179.

Arnold LL, Eldan M, Nyska A, van Gemert M, Cohen SM. 2006. Dimethylarsinic acid: Results of chronic toxicity/oncogenicity studies in F344 rats and in B6C3F1 mice. Toxicology 223:82-100.

Barker S, Weinfeld M, Murray D. 2005. DNA-protein crosslinks: their induction, repair, and biological consequences. Mutat Res 589:111-135.

Basu A, Ghosh P, Das JK, Banerjee A, Ray K, Giri AK. 2004. Micronuclei as biomarkers of carcinogen exposure in populations exposed to arsenic through drinking water in West Bengal, India: A comparative study in three cell types. Cancer Epidemiol Biomarkers Prev 13:820-827.

Beijnen JH, van Gijn R, Challa EE, Kaijser GP, Underberg WJ. 1992. Chemical stability of two sterile, parenteral formulations of cyclophosphamide (Endoxan) after reconstitution and dilution in commonly used infusion fluids. J Parenter Sci Technol 46:111-116.

Bowman DL, Smith CJ, Bombick BR, Avalos JT, Davis RA, Morgan WT, Doolittle DJ. 2002. Relationship between FTC 'tar' and urine mutagenicity in smokers of tobacco-burning or Eclipse cigarettes. Mutat Res 521:137-149.

Chakraborty T, Das U, Poddar S, Sengupta B, De M. 2006. Micronuclei and chromosomal aberrations as biomarkers: a study in an arsenic exposed population in West Bengal, India Bull Environ Contam Toxicol 76:970-976.

Chiou HY, Chiou ST, Hsu YH, Chou YL, Tseng CH, Wei ML, Chen CJ. 2001. Incidence of transitional cell carcinoma and arsenic in drinking water: A follow-up study of 8,102 residents in an arseniasis-endemic area in northeastern Taiwan. Am J Epidemiol 153: 411-418.

Clewell HJ, Gentry PR, McDonald TB, Yager JW. 2006. Biologically based dose-response modeling for arsenic. Workshop on arsenic research and risk assessment. Shepherdsteon, WU. US, EPA 49-53

Cohen SM, Arnold LL, Uzvolgyi E, Cano M, St John M, Yamamoto S, Lu X, Le XC. 2002. Possible role of dimethylarsinous acid in dimethylarsinic acid-induced urothelial toxicity and regeneration in the rat. Chem Res Toxicol 15:1150-1157.
Cohen SM, Ohnishi T, Arnold LL, Le XC. 2007. Arsenic-induced bladder cancer in an animal model. Toxicol Appl Pharmacol 222:258-263.

Cohen SM, Yamamoto S, Cano M, Arnold LL. 2001. Urothelial cytotoxicity and regeneration induced by dimethylarsinic acid in rats. Toxicol Sci 59:68-74.

de Jonge ME, Huitema AD, Rodenhuis S, Beijnen JH. 2005. Clinical pharmacokinetics of cyclophosphamide. Clin Pharmacokinet 44:1135-1164.

Dopp E, Hartmann LM, Florea AM, von Recklinghausen U, Pieper R, Shokouhi B, Rettenmeier AW, Hirner AV, Obe G. 2004. Uptake of inorganic and organic derivatives of arsenic associated with induced cytotoxic and genotoxic effects in Chinese hamster ovary (CHO) cells. Toxicol Appl Pharmacol 201:156-165.

Feng Z, Xia Y, Tian D, Wu K, Schmitt M, Kwok RK, Mumford JL. 2001. DNA damage in buccal epithelial cells from individuals chronically exposed to arsenic via drinking water in Inner Mongolia, China. Anticancer Res 21:51-57.

Guo HR, Wang NS, Hu H, Monson RR. 2004. Cell type specificity of lung cancer associated with arsenic ingestion. Cancer Epidemiol Biomarkers Prev 13:638-643.

Guo HR, Yu HS, Hu H, Monson RR. 2001. Arsenic in drinking water and skin cancers: Cell-type specificity (Taiwan, ROC). Cancer Causes Control 12:909-916.

Hamadeh HK, Trouba KJ, Amin RP, Afshari CA, Germolec D. 2002. Coordination of altered DNA repair and damage pathways in arsenite-exposed keratinocytes. Toxicol Sci 69:306-316.

Hartwig A, Pelzer A, Asmuss M, Burkle A. 2003. Very low concentrations of arsenite suppress poly(ADP-ribosyl)ation in mammalian cells. Int J Cancer 104:1-6.

Ho IC, Yih LH, Kao CY, Lee TC. 2000. Tin-protoporphyrin potentiates arsenite-induced DNA strand breaks, chromatid breaks and kinetochore-negative micronuclei in human fibroblasts. Mutat Res 452:41-50.

Huff J, Chan P, Waalkes M. 1998. Arsenic carcinogenicity testing. Environ Health Perspect 106:A170.

Hughes MF, Kenyon EM, Edwards BC, Mitchell CT, Razo LM, Thomas DJ. 2003. Accumulation and metabolism of arsenic in mice after repeated oral administration of arsenate. Toxicol Appl Pharmacol 191:202-210.

IARC. 1987. Cyclophosphamide. Lyon Cedex, France: IARC Press.

IARC. 2004. IARC Monographs on the evaluation of carcinogenic risks to humans: Some drinking-water disinfectants and contaminants, including arsenic. Lyon Cedex, France: IARC Press.

IARC. 2006. Formaldehyde, 2-Butoxyethanol and 1-tert-Butoxypropan-2ol. Lyon Cedex, France: IARC Press. 478 p.

Kato K, Yamanaka K, Hasegawa A, Okada S. 2003. Active arsenic species produced by GSH-dependent reduction of dimethylarsinic acid cause micronuclei formation in peripheral reticulocytes of mice. Mutat Res 539:55-63.

Kawakami T, Shiina H, Igawa M, Deguchi M, Nakajima K, Ogishima T, Tokizane T, Urakami S, Enokida H, Miura K, others. 2004. Inactivation of the hMSH3 mismatch repair gene in bladder cancer. Biochem Biophys Res Commun 325:934-942.

Kircelli F, Akay C, Gazitt Y. 2007. Arsenic trioxide induces p53-dependent apoptotic signals in myeloma cells with SiRNA-silenced p53: MAP kinase pathway is preferentially activated in cells expressing inactivated p53. Int J Oncol 30:993-1001.

Kitchin KT. 2001. Recent advances in arsenic carcinogenesis: Modes of action, animal model systems, and methylated arsenic metabolites. Toxicol Appl Pharmacol 172:249-261.

Kligerman AD, Tennant AH. 2006. Insights into the carcinogenic mode of action of arsenic. Toxicol Appl Pharmacol 222:281-288.

Komissarova EV, Saha SK, Rossman TG. 2005. Dead or dying: The importance of time in cytotoxicity assays using arsenite as an example. Toxicol Appl Pharmacol 202:99-107. 
Korabiowska M, Quentin T, Schlott T, Bauer H, Kunze E. 2004. Downregulation of $\mathrm{Ku} 70$ and $\mathrm{Ku} 80$ mRNA expression in transitional cell carcinomas of the urinary bladder related to tumor progression. World J Urol 22:431-440.

Le XC, Weinfeld M. 2004. Additive Effects of Sodium Arsenite and $\gamma$ Ratiation. Cellular Responses to Arsenic: DNA Damage and Defense Mechanisms Denvor. CO:AWWA Research Foundation. pp 25-34.

Lewinska D, Arkusz J, Stanczyk M, Palus J, Dziubaltowska E, Stepnik M. 2007. Comparison of the effects of arsenic and cadmium on benzo. (a) pyrene-induced micronuclei in mouse bone-marrow. Mutat Res: Genet Toxicol Environ Mutagen 632:37-43.

Lu M, Wang H, Li XF, Lu X, Cullen WR, Arnold LL, Cohen SM, Le XC. 2004. Evidence of hemoglobin binding to arsenic as a basis for the accumulation of arsenic in rat blood. Chem Res Toxicol 17:1733-1742.

Moore LE, Smith AH, Eng C, Kalman D, DeVries S, Bhargava V, Chew K, Moore D, 2nd, Ferreccio C, Rey OA, others. 2002. Arsenicrelated chromosomal alterations in bladder cancer. J Natl Cancer Inst 94:1688-1696.

Moore LE, Smith AH, Hopenhayn-Rich C, Biggs ML, Kalman DA, Smith MT. 1997. Micronuclei in exfoliated bladder cells among individuals chronically exposed to arsenic in drinking water. Cancer Epidemiol Biomarkers Prev 6:31-36.

Palus J, Lewinska D, Dziubaltowska E, Wasowicz W, Gromadzinska J, Rydzynski K, Stanczyk M, Arkusz J, Trzcinka-Ochocka M, Stepnik M. 2006. Genotoxic effects in $\mathrm{C} 57 \mathrm{Bl} / 6 \mathrm{~J}$ mice chronically exposed to arsenate in drinking water and modulation of the effects by low-selenium diet. J Toxicol Environ Health A 69:1843-1860.

Patlolla AK, Tchounwou PB. 2005. Cytogenetic evaluation of arsenic trioxide toxicity in Sprague-Dawley rats. Mutat Res 587:126-133.

Quievryn G, Zhitkovich A. 2000. Loss of DNA-protein crosslinks from formaldehyde-exposed cells occurs through spontaneous hydrolysis and an active repair process linked to proteosome function. Carcinogenesis 21:1573-1580.

Rossi MR, Masters JR, Park S, Todd JH, Garrett SH, Sens MA, Somji S, Nath J, Sens DA. 2001. The immortalized UROtsa cell line as a potential cell culture model of human urothelium. Environ Health Perspect 109:801-808.

Rossman TG. 2003. Mechanism of arsenic carcinogenesis: An integrated approach. Mutat Res 533:37-65.

Rossman TG, Uddin AN, Burns FJ. 2004. Evidence that arsenite acts as a cocarcinogen in skin cancer. Toxicol Appl Pharmacol 198:394-404.

Sams IIR, Wolf DC, Ramasamy S, Ohanian E, Chen J, Lowit A. 2007. Workshop overview: Arsenic research and risk assessment. Toxicol Appl Pharmacol 222:245-251.

Schoen A, Beck B, Sharma R, Dube E. 2004. Arsenic toxicity at low doses: Epidemiological and mode of action considerations. Toxicol Appl Pharmacol 198:253-267.

Schwerdtle T, Walter I, Hartwig A. 2003. Arsenite and its biomethylated metabolites interfere with the formation and repair of stable BPDE-induced DNA adducts in human cells and impair XPAzf and Fpg. DNA Repair (Amst) 2:1449-1463.

Shen J, Wanibuchi H, Waalkes MP, Salim EI, Kinoshita A, Yoshida K, Endo G, Fukushima S. 2006. A comparative study of the sub- chronic toxic effects of three organic arsenical compounds on the urothelium in F344 rats; gender-based differences in response. Toxicol Appl Pharmacol 210:171-180.

Su PF, Hu YJ, Ho IC, Cheng YM, Lee TC. 2006. Distinct gene expression profiles in immortalized human urothelial cells exposed to inorganic arsenite and its methylated trivalent metabolites. Environ Health Perspect 114:394-403.

Tian D, Ma H, Feng Z, Xia Y, Le XC, Ni Z, Allen J, Collins B, Schreinemachers D, Mumford JL. 2001. Analyses of micronuclei in exfoliated epithelial cells from individuals chronically exposed to arsenic via drinking water in inner Mongolia. China J Toxicol Environ Health A 64:473-484.

Vogt BL, Rossman TG. 2001. Effects of arsenite on p53, p21 and cyclin D expression in normal human fibroblasts-A possible mechanism for arsenite's comutagenicity. Mutat Res 478:159-168.

Wang JP, Qi L, Moore MR, Ng JC. 2002. A review of animal models for the study of arsenic carcinogenesis. Toxicol Lett 133:1731.

Wang A, Robertson JL, Holladay SD, Tennant AH, Lengi AJ, Ahmed SA, Huckle WR, Kligerman AD. 2007a. Measurement of DNA damage in rat urinary bladder transitional cells: Improved selective harvest of transitional cells and detailed Comet assay protocols. Mutat Res 634:51-59.

Wang TC, Jan KY, Wang AS, Gurr JR. 2007b. Trivalent arsenicals induce lipid peroxidation, protein carbonylation, and oxidative DNA damage in human urothelial cells. Mutat Res 615:7586.

Warner ML, Moore LE, Smith MT, Kalman DA, Fanning E, Smith AH. 1994. Increased micronuclei in exfoliated bladder cells of individuals who chronically ingest arsenic-contaminated water in Nevada. Cancer Epidemiol Biomarkers Prev 3:583-590.

Wei M, Arnold L, Cano M, Cohen SM. 2005. Effects of co-administration of antioxidants and arsenicals on the rat urinary bladder epithelium. Toxicol Sci 83:237-245.

Wei M, Wanibuchi H, Morimura K, Iwai S, Yoshida K, Endo G, Nakae D, Fukushima S. 2002. Carcinogenicity of dimethylarsinic acid in male F344 rats and genetic alterations in induced urinary bladder tumors. Carcinogenesis 23:1387-1397.

Wei M, Wanibuchi H, Yamamoto S, Li W, Fukushima S. 1999. Urinary bladder carcinogenicity of dimethylarsinic acid in male F344 rats. Carcinogenesis 20:1873-1876.

Wu F, Burns FJ, Zhang R, Uddin AN, Rossman TG. 2005. Arseniteinduced alterations of DNA photodamage repair and apoptosis after solar-simulation UVR in mouse keratinocytes in vitro. Environ Health Perspect 113:983-986.

Yamanaka K, Hasegawa A, Sawamura R, Okada S. 1989. DNA strand breaks in mammalian tissues induced by methylarsenics. Biol Trace Elem Res 21:413-417.

Yoshimi N, Shinoda T, Tanaka T, Mori Y, Mori H. 1989. Reduced DNA repair response of carcinogen-induced hyperplastic cells in rat urinary bladder exposed to $N$-methyl- $N N^{\prime}$-nitro- $N$-nitrosoguanidine in organ culture. Res Commun Chem Pathol Pharmacol 63:93-100.

Accepted byC. Klein 